\title{
Galectin-3 in autoimmunity and autoimmune diseases
}

\author{
Felipe L de Oliveira ${ }^{1,2}$, Mariele Gatto ${ }^{2}$, Nicola Bassi ${ }^{2}$, Roberto Luisetto ${ }^{2}$, Anna Ghirardello ${ }^{2}$, \\ Leonardo Punzi ${ }^{2}$ and Andrea Doria ${ }^{2}$
}

${ }^{1}$ Coimbra Group Fellowship for Latin American Professors, Instituto de Ciências Biomédicas, Universidade Federal do Rio de Janeiro, Rio de Janeiro, RJ CEP 21941-902, Brazil; ${ }^{2}$ Rheumatology Unit, Department of Medicine, University of Padova, Padova 35128 , Italy

Corresponding author: Andrea Doria. Email: adoria@unipd.it

\begin{abstract}
Galectin-3 (gal-3) is a $\beta$-galactoside-binding lectin, which regulates cell-cell and extracellular interactions during self/ non-self-antigen recognition and cellular activation, proliferation, differentiation, migration and apoptosis. It plays a significant role in cellular and tissue pathophysiology by organizing niches that drive inflammation and immune responses. Gal-3 has some therapeutic potential in several diseases, including chronic inflammatory disorders, cancer and autoimmune diseases. Gal-3 exerts a broad spectrum of functions which differs according to its intra- or extracellular localization. Recombinant gal-3 strategy has been used to identify potential mode of action of gal-3; however, exogenous gal-3 may not reproduce the functions of the endogenous gal-3. Notably, gal-3 induces monocyte-macrophage differentiation, interferes with dendritic cell fate decision, regulates apoptosis on $\mathrm{T}$ lymphocytes and inhibits B-lymphocyte differentiation into immunoglobulin secreting plasma cells. Considering the influence of these cell populations in the pathogenesis of several autoimmune diseases, gal-3 seems to play a role in development of autoimmunity. Gal-3 has been suggested as a potential therapeutic agent in patients affected with some autoimmune disorders. However, the precise role of gal-3 in driving the inflammatory process in autoimmune or immune-mediated disorders remains elusive. Here, we reviewed the involvement of gal-3 in cellular and tissue events during autoimmune and immune-mediated inflammatory diseases.
\end{abstract}

Keywords: Galectin-3, autoimmunity, autoimmune diseases

Experimental Biology and Medicine 2015; 240: 1019-1028. DOI: 10.1177/1535370215593826

\section{Introduction}

Galectin-3 (gal-3) is a $\beta$-galactoside-binding protein which regulates cell-cell and cell-extracellular matrix interactions affecting cell proliferation, migration, adhesion, differentiation and apoptosis. ${ }^{1}$ Gal-3 is produced by macrophages, monocytes, dendritic cells (DCs), eosinophils, mast cells, NK cells and activated T and B cells. ${ }^{2,3}$ During the past decade, gal-3 has attracted the attention of researchers due to its regulatory role in immune response, inflammation and fibrosis. ${ }^{4,5}$

The biological activities are structurally linked to C-terminal carbohydrate recognition domain (CRD)) and $\mathrm{N}$-terminal domain enriched by proline and glycine (protein recognition domain) responsible for specific interactions. ${ }^{1}$ Moreover, gal-3 regulates the expression of several regulatory genes ${ }^{6}$ and forms lattices with cell-surface glycoprotein receptors and senses self-derived or pathogen glycoconjugates when located on cell surfaces. ${ }^{7}$ Indeed, gal-3 controls immune responses through damage-associated molecular pattern (DAMP) ) and pathogen-associated molecular pattern (PAMP) pathways. ${ }^{8}$ It is able to recognize endogenous ("self") and exogenous ("non-self") carbohydrate compounds eliciting complex immune and autoimmune responses. $^{9}$

\section{Galectin-3 and the immune response: An overview}

The effects of gal-3 clearly depend on cellular or tissue localization. In order to identify therapeutic targets, recombinant gal-3 has been used in distinct experimental models, including heart failure and liver diseases where it can mimic the extracellular functions of this molecule. ${ }^{5,10}$ Functions of endogenous gal-3 have been widely studied in tumors, where gal-3 seems to play a role in cell transformation, proliferation, metastasis and apoptosis. ${ }^{11}$ Recombinant gal-3 may not affect the functions of the endogenous protein, which is also influenced by gal-3 antagonists, including GCS-100, which dampens tumor growth and metastasis in distinct experimental models. ${ }^{12}$ The identification of the cell compartment where gal-3 is detected is crucial in order to understand the effects of this molecule on cell function. ${ }^{11}$ 
In mice, gal-3 is poorly expressed by resting $\mathrm{T}$ and $\mathrm{B}$ cells, being up-regulated after activation. ${ }^{3,13,14}$ On the other hand, in humans, gal-3 is constitutively expressed by regulatory $\left(\mathrm{T}_{\text {reg }}\right)$ and $\mathrm{CD} 4^{+}$memory $\mathrm{T}$ cells. ${ }^{15}$ Extracellular gal-3 induces T-cell apoptosis, ${ }^{16}$ migration of $\mathrm{CD}^{+} / \mathrm{CD}^{+}$ thymocytes on laminin, ${ }^{17}$ and T-cell activation resulting in intracellular calcium influx. ${ }^{18}$ Intracellular gal-3 inhibits apoptosis ${ }^{19}$ and interleukin (IL)-5 expression, ${ }^{20}$ promotes cell growth and negatively regulates TCR-mediated CD4 T-cell activation at immunological synapses. ${ }^{21}$

As far as B lymphocyte subpopulations are concerned, gal-3 regulates $\mathrm{B}_{220^{+}}$and $\mathrm{CD} 138^{+}$cell niches in lymphoid tissues $^{22}$ and inhibits plasma cell differentiation in vitro ${ }^{3}$ and in vivo in the bone marrow, mesenteric lymph nodes and spleen. ${ }^{22-24}$ Moreover, gal-3 inhibits B-cell differentiation into plasma cells in distinct lymphoid tissues, ${ }^{23-25}$ plays anti-apoptotic functions on proliferative B-cell neoplasms $^{26}$ and maintains B-cell anergy. ${ }^{27}$

The advent of gal-3 deficient mice (gal- $3^{-/-}$mice) allowed more detailed studies on immunomodulatory mechanisms of gal- $3 .^{28}$ The absence of gal- 3 enhances $\mathrm{T}_{\mathrm{H}} 1$ or $\mathrm{T}_{\mathrm{H}} 2$ immune responses depending on experimental model ${ }^{29-31}$; indeed, it has been shown that gal-3 controls lymphocyte behavior during immune responses and exerts a potential role in the regulation of autoantibody production. ${ }^{24,31,32}$ Gal- $3^{-/-}$mice have an intense plasmacytogenesis and hypergammaglobulinemia as well as follicular $\mathrm{B}$ cells highly susceptible to apoptotic stimuli. ${ }^{22-24}$ In addition, autoantibody transgenic mice lacking gal-3 (and also gal-1) have spontaneous anti-laminin-secreting plasma cell differentiation in the spleen followed by B-cell depletion and anergy. ${ }^{27}$ These data suggest that gal-3 plays a central role in maintaining B-cell tolerance. Here, we discuss whether gal-3 is involved in the pathogenesis of some autoimmune diseases and whether or not it might represent a treatment target (Table 1).

\section{Systemic lupus erythematosus}

Systemic lupus erythematosus (SLE) is a complex autoimmune multi-organ disorder in which genetic predisposition, environmental triggers and imbalanced immune response lead to autoantibody secretion and tissue injury. ${ }^{33,34}$ Beside autoreactive B lymphocytes and autoantibody-secreting plasma cells, $T_{\text {reg }}$ cells, NKT cells, mesenchymal stem cells, DCs and autoreactive $\mathrm{T}$ cells are also involved in the immunopathogenesis of SLE. ${ }^{34-36}$

Mice susceptible to autoimmune diseases, including lupus, have abnormal germinal center reactions, which seem essential in triggering autoimmune signals. ${ }^{37}$ Spontaneously generated splenic germinal centers were associated with autoantibody production and atypical distribution of $\mathrm{B}^{2} 20^{+} \mathrm{PNA}^{+}$(peanut agglutinin) GL-7 ${ }^{+}$(Ly77 or B-/T-cell activation marker) B cells and $\mathrm{M}^{+}$(Murine 1) follicular DCs. ${ }^{38}$ Splenic follicular gal- $3^{+}$cells have DC morphology, ${ }^{39}$ but it is not clear whether follicular macrophages also express gal-3 within lymphoid follicles. ${ }^{22}$ In gal-3 ${ }^{-/-}$mice chronically infected by helminthes, such as Schistosoma mansoni, niches of $\mathrm{CD} 138^{+}$plasma cells and $\mathrm{B}_{220^{+}} \mathrm{B}$ lymphocytes were severely disturbed in the spleen and mesenteric lymph nodes, affecting the activation and survival of these cells. Moreover, the high number of follicular apoptotic bodies indicates that gal-3 is an important mediator of apoptosis and/or clearance in these lymphoid organs. ${ }^{22}$ Notably, both mechanisms are involved in the pathogenesis of SLE and other autoimmune diseases. ${ }^{40}$

In the thymus, exogenous gal-3 plays a de-adhesive role favoring intrathymic migration of CD4/CD8 T cells during differentiation events. ${ }^{41}$ By contrast, intracellular gal-3 suppresses $\mathrm{T}_{\mathrm{H}} 17$ phenotype by inhibiting IL-23/IL-17-axis in DCs. ${ }^{42}$

In gal- $3^{-/-}$mice, the serum levels of IL-23, transforming growth factor (TGF)- $\beta 1$ and IL-1 $\beta$ were significantly increased leading to a decrease in IL-12, interferon (IFN)-gamma and $\mathrm{T}_{\mathrm{H}} 1$ cells. ${ }^{43}$ Since SLE progression is critically associated with pro-inflammatory $\mathrm{T}_{\mathrm{H}} 17$ cells secreting IL-17, IL-1, IL-6 and IL-23, ${ }^{44}$ it is likely that gal-3 plays a regulatory role in the pathogenesis of SLE by suppressing $\mathrm{T}_{\mathrm{H}} 17$ cell differentiation.

SLE patients with predominant type I IFN signature have a high rate of macrophage differentiation and autoantibody production leading to a more severe disease. ${ }^{45}$ Plasmacytoid DCs (pDCs) responsible for type I IFN signature are activated by self-nucleic acid complexes via CD32 and toll-like receptor (TLR)-9. ${ }^{46}$ Self-nucleic acid complexes are abundantly released by apoptotic cells and by neutrophils during neutrophil extracellular traps formation. ${ }^{47}$

On peripheral blood mononuclear cells, gal-3/CD32 (low-affinity IgG receptor-Fcgamma RII) interaction inhibits $\mathrm{T}_{\mathrm{H}} 2$ cytokine responses and favors a type I IFN phenotype. ${ }^{18}$ It is well known that the inhibition of type I IFN signals leads to a delayed symptoms in experimental $\mathrm{SLE}^{48}$; thus, gal-3 could promote SLE by increasing type I IFN expression.

Another mechanism potentially involved in gal-3 inducing SLE development consists in the interaction with transcription factors that induce B-/T-cell differentiation and hypergammaglobulinemia, such as Blimp-1 (B lymphocyte-induced maturation protein-1) which follows DC activation. ${ }^{49}$ In MRL.Fas ${ }^{\text {lpr }}$ mice, the absence of DCs leads to milder SLE symptoms, reduced T-/B-cell expansion and lower production of autoantibodies. ${ }^{50}$ Although poorly explored in SLE, polymorphisms in Blimp-1 have been proposed as a "risk factor" for SLE. ${ }^{49}$ Inhibition/deletion of gal-3 in vivo leads to up-regulation of Blimp-1 affecting plasma cell behavior, survival and synthesis of $\operatorname{IgG}$ and IgE. $^{3,24}$

IgG anti-galectins have been reported during the early stage and progression of SLE, especially anti-gal-2, $-3,-7$, -8 and $-9 .{ }^{51}$ In humans, anti-gal-3 autoantibody serum levels were significantly higher in SLE patients than in healthy donors or in patients with rheumatoid arthritis (RA), primary Sjögren's syndrome (pSS) and systemic sclerosis (SSc). ${ }^{52}$

As far as clinical manifestations are concerned, Shi et al. found an association between anti-gal-3 antibodies and SLE cutaneous vasculitis. Indeed, SLE patients bearing skin lesions have high serum levels of anti-gal-3 autoantibodies, which are localized on the vessel walls. Notably, 
Table 1 Galectin-3 expression, association with different autoimmune diseases and potential mechanisms of action

\begin{tabular}{|c|c|c|c|c|c|}
\hline Disease & $\begin{array}{l}\text { Expression and/ } \\
\text { or level of galectin-3 }\end{array}$ & $\begin{array}{l}\text { Association with clinical } \\
\text { findings }\end{array}$ & Target cells & Cellular effects & Ref. \\
\hline SLE & $\begin{array}{l}\text { Overexpressed in mesangial } \\
\text { cells in patients with } \\
\text { lupus GN }\end{array}$ & $\begin{array}{l}\text { High levels of autoantibodies } \\
\text { anti-gal- } 3 \text { in lupus GN and } \\
\text { skin vasculitis }\end{array}$ & $\begin{array}{l}\text { B lymphocytes } \\
\text { pDCs } \\
T_{H} 17 \text { cells } \\
\text { Mesangial cells }\end{array}$ & $\begin{array}{l}\text { High IgG secretion dependent } \\
\text { on Blimp-1 expression } \\
\text { High type } 1 \text { IFN } \\
\mathrm{T}_{\mathrm{H}} 2 \text { signature } \\
\text { GBM abnormalities } \\
\text { Mesangial hypercellularity } \\
\text { Apoptosis disturbance }\end{array}$ & $38,51-53$ \\
\hline RA & $\begin{array}{l}\text { Overexpressed in synovial } \\
\text { membrane } \\
\text { High levels in the serum } \\
\text { during CIA }\end{array}$ & $\begin{array}{l}\text { High CRP in humans } \\
\text { High IL- } 6 \text {, TNF- } \alpha \text {, IL-17 serum } \\
\text { levels in mice }\end{array}$ & $\begin{array}{l}\text { Synovial cells } \\
\text { B lymphocytes } \\
\text { T lymphocytes }\end{array}$ & $\begin{array}{l}\text { High IL-6, GM-CSF, CXCL8, } \\
\text { MMP-3, TNF- } \alpha \text {, CCL2, CCL3, } \\
\text { and CCL5 production by } \\
\text { synovial fibroblasts } \\
\text { Gal-3 }{ }^{-/-} \text {mice have low IgG, } \\
\text { IL-6, TNF- } \alpha \text {, and IL-17 }\end{array}$ & $62-64$ \\
\hline $\mathrm{PM} / \mathrm{DM}$ & ND & $\begin{array}{l}\text { High levels of autoantibodies } \\
\text { in the serum }\end{array}$ & $\begin{array}{l}\text { B lymphocytes } \\
\text { T lymphocytes }\end{array}$ & $\begin{array}{l}\text { Type } 1 \text { IFN pathway } \\
\text { Involved in complement } \\
\text { activation }\end{array}$ & $69-71$ \\
\hline pSS & High serum levels & $\begin{array}{l}\text { High CRP, fibrinogen, IgG } \\
\text { and IL-17 }\end{array}$ & $\begin{array}{l}\text { B lymphocytes } \\
\text { Stromal cells }\end{array}$ & $\begin{array}{l}\text { Leukocyte recruitment to } \\
\text { exocrine glands } \\
\text { Pro-fibrotic events }\end{array}$ & 78 \\
\hline GN & $\begin{array}{l}\text { Up-regulated in glomerular } \\
\text { cells }\end{array}$ & $\begin{array}{l}\text { Mesangial hypercellularity } \\
\text { Renal damage }\end{array}$ & Mesangial cells & $\begin{array}{l}\text { Anti-apoptotic effects } \\
\text { AGE accumulation } \\
\text { Oxidative stress }\end{array}$ & 54,84 \\
\hline Psoriasis & $\begin{array}{l}\text { Up-regulated in dermal } \\
\text { endothelium } \\
\text { Down-modulated in } \\
\text { epidermal cells and } \\
\text { Langerhans cells }\end{array}$ & ND & $\begin{array}{l}\text { mDCs } \\
\text { Keratinocytes }\end{array}$ & $\begin{array}{l}\text { High IL-12+/IL-23 + cell } \\
\text { differentiation } \\
\text { High IL-17, IFN- } \gamma \text {, TNF, and } \\
\text { IL-22 synthesis }\end{array}$ & 90,91 \\
\hline T1D & ND & ND & Pancreatic $\beta$ cells & $\begin{array}{l}\text { Apoptosis mediated by } \\
\text { TNF- } \alpha / \text { IFN }-\gamma / \mathrm{IL}-1 \beta\end{array}$ & $111-114$ \\
\hline $\mathrm{AiH}$ & $\begin{array}{l}\text { Up-regulated in myofibro- } \\
\text { blasts during liver fibrosis }\end{array}$ & $\begin{array}{l}\text { Liver fibrosis } \\
\text { Cirrhosis }\end{array}$ & $\begin{array}{l}\text { Hepatocytes } \\
T_{H} 1 / T_{H} 17 \text { cells } \\
\text { Hepatic stellate } \\
\quad \text { cells }\end{array}$ & $\begin{array}{l}\text { Apoptosis } \\
\text { Pro-inflammatory cytokines } \\
\text { Differentiation into myofibro- } \\
\quad \text { blasts and fibrosis }\end{array}$ & 122,125 \\
\hline $\begin{array}{l}\text { Crohn's } \\
\text { Disease }\end{array}$ & $\begin{array}{l}\text { Down-regulated in colonic } \\
\text { epithelial cells } \\
\text { High serum levels }\end{array}$ & $\begin{array}{l}\text { Serum IgG anti-gal-3 inversely } \\
\text { correlated with clinical } \\
\text { symptoms in active disease } \\
\text { Fistula formation }\end{array}$ & $\begin{array}{l}\text { Colonic epithelial } \\
\quad \text { cells } \\
\text { Fibroblasts }\end{array}$ & $\begin{array}{l}\text { Epithelial cell-cell interactions } \\
\text { Production of IL-8 } \\
\text { Fistula formation }\end{array}$ & 128,129 \\
\hline
\end{tabular}

SLE: systemic lupus erythematosus; RA: rheumatoid arthritis; pSS: primary Sjögren syndrome; SSc: systemic sclerosis; PM/DM: polymositis/dermatomyositis; AD: atopic dermatitis; MS: multiple sclerosis; EAE: experimental autoimmune encephalomyelitis; T1D: Type 1 diabetes; AiH: autoimmune hepatitis; GN: glomerulonephritis; GBM: glomerular basement membrane; IgG: immunoglobulin G; ND: not detectable; OVA: ovalbumin; gal-3: galectin 3; CRP: C-reactive protein; IL: interleukin; pDCs: plasmacytoid dendritic cells; mDCs: myeloid dendritic cells; Th: T helper, Blimp-1: B lymphocyte-induced maturation protein-1; AGE: advanced glycation end product CCL: chemokine (C-C motif) ligand; CXCL: chemokine (C-X-C) motif ligand; TNF: tumor necrosis factor; IFN: interferon; Ras: Rat sarcoma protein; PI-3: phosphoinositide-3 kinase, CIA: collagen-induced arthritis. 
the injection of anti-human gal-3 antibodies in BALB/c mice evoked a dermal vasculitis $36 \mathrm{~h}$ post injection. ${ }^{53}$

Gal-3 and anti-gal-3 antibodies might also be involved in development of lupus nephritis, which affects approximately $50-60 \%$ of SLE patients. ${ }^{54}$ During the early phases of lupus nephritis, autoimmune $\mathrm{T}$ cells respond to tissue injuries reacting against chromatin or nucleosomes derived from cell death, including apoptosis, necrosis, necroptosis, autophagy and possible disturbances in the clearance of dying cells, leading to differentiation of autoimmune lymphocytes. ${ }^{55,56}$

Interestingly, SLE patients affected with lupus nephritis were seen to display higher serum levels of anti-gal-3 antibodies compared with controls; additionally, gal-3 stained in glomeruli in the majority of patients, while it was absent in controls. ${ }^{38}$ Notably, gal-3 was expressed in distal tubules of normal kidneys. ${ }^{38}$ Gal-3 expression scores correlated with anti-double stranded (ds) DNA antibody titers, renal histological activity indexes and complement consumption in SLE patients. ${ }^{38}$

In rats, gal-3 modulates mesangial cell proliferation and matrix synthesis during experimental glomerulonephritis. Moreover, it was demonstrated that gal-3 is significantly secreted by infiltrating macrophages and distal tubular epithelium. ${ }^{57}$ Recently, Nielsen et al. ${ }^{58}$ revealed an increased population of gal-3-binding protein (G3BP)-positive microparticles either in sera or in electron-dense deposits from kidney biopsies of SLE patients affected with lupus nephritis, suggesting that gal-3 co-localizes in immune complex deposits. These observations support the potential role of gal-3 as a putative autoantigen in development of specific lupus manifestations.

Taking into account these data, whether gal-3 is involved in fueling or dampening SLE pathways is currently unclear (Table 1).

\section{Rheumatoid arthritis}

RA is an autoimmune disease characterized by an aberrant immune response against citrullinated self-peptides and progressive joint destruction. ${ }^{59}$ Failure in $\mathrm{CD}^{+} \mathrm{T}_{\text {reg }}{ }^{-}$ mediated self-tolerance and increase in $\mathrm{T}_{\mathrm{H}} 17$ cells seem to be critical in the immunopathogenesis of RA. ${ }^{60}$ Indeed, in RA synovitis, the inflammatory process is orchestrated by activated monocytes (secreting IL-1 $\beta$, IL-6, IL-7 and tumor necrosis factor-alpha (TNF)- $\alpha$ ), fibroblast-like synoviocytes (synthesizing metalloproteases, chemokines and cytokines, mainly IL-15), and dysregulated osteoclasts (due to high levels of TNF- $\alpha$ and IL-17). ${ }^{61}$

Gal-3 seems to play a pro-inflammatory role in $\mathrm{RA}^{62}$ and high serum levels of gal-3 have been found in mice during collagen-induced arthritis. ${ }^{63}$ In humans, gal-3 mRNA and protein are overexpressed in the synovial membrane close to joint destruction and are highly correlated with C-reactive protein (CRP) serum levels and IL-6, granulocyte-macrophage colony stimulating factor (GM-CSF), chemokine (C-X-C) motif ligand 8 (CXCL8), metalloproteinase-3 (MMP-3), TNF- $\alpha$, chemokine (C-C motif) ligand 2 (CCL2), CCL3 and CCL5 secretion by synovial fibroblasts. ${ }^{64}$ The lack of gal-3 prevented antigen-induced arthritis in mice which showed lower levels of antigen-specific IgG, IL-6, TNF- $\alpha$ and IL-17. ${ }^{62}$

Genetic polymorphisms in gal-3 gene seem to be involved in RA susceptibility. Indeed, it has recently been shown that gal-3 gene (LGALS3) $+292 \mathrm{C}$ allele is associated with RA in Taiwanese population. ${ }^{65}$ Notably, recombinant gal-3 in gal-3 ${ }^{-/-}$mice can restore RA symptoms and cytokine production. ${ }^{62}$ Finally, gal-3 short hairpin RNA (shRNA) injected in inflamed joints reduced collageninduced arthritis in rats. ${ }^{63}$ Thus, gal-3 is likely to play a critical role in RA development by regulating synovial fibroblast functions (Table 1).

\section{Systemic sclerosis}

SSc is a heterogeneous autoimmune disease characterized by progressive fibrosis of skin and internal organs due to an abnormal and chronic activation of fibroblasts. ${ }^{66} \mathrm{Gal}-3$ has been suggested to play a key role in inducing fibrosis in different tissues. ${ }^{5}$ Gal-3 serum levels are substantially increased in SSc patients where they seem to be correlated with the fibrotic process; in fact, gal-3 seems to regulate fibroblast activation, one of the major pathways responsible for fibrosis in SSc. ${ }^{67}$ Indeed, gal-3 serum levels were not increased in the early stages of diffuse SSc but they progressively increased over disease course. ${ }^{68}$ Thus, gal-3 represents an interesting molecule, potentially involved in the pathogenesis of SSc, which can help us to better understand the mechanisms of fibrogenesis in experimental models and humans (Table 1). It might also represent a therapeutic target in SSc.

\section{Polymyositis/dermatomyositis}

Polymyositis and dermatomyositis are considered the two major subsets of idiopathic inflammatory myopathies. ${ }^{69}$ Polymyositis is characterized by a $\mathrm{CD} 8^{+} \mathrm{T}$-cell response against muscle antigens presented by MHC Class I molecules. On the other hand, dermatomyositis is marked by a complement-mediated microangiopathy, typically mediated by type I IFN phenotype and autoantibodies with distinct specificities ${ }^{70,71}$; however, the exact mechanism involved in complement activation remains unclear. ${ }^{72}$ Current biological treatments in polymyositis/dermatomyositis include blockade of cells and cytokines, including B-cells by rituximab, ${ }^{73}$ Tcells by abatacept and cytokines by anti-IL-1, anti-IL-6 or anti-IFN $\alpha$ monoclonal antibodies. ${ }^{74}$

Autoantibodies to gal-3 were found more frequently in the sera of patients with polymyositis/dermatomyositis than in those with other autoimmune diseases, including RA, pSS, SSc and SLE. ${ }^{52}$ However, the analysis of sensitivity and specificity of these autoantibodies in large cohorts of patients is critical in order to determine whether anti-gal-3 could be used as diagnostic marker in patients with polymyositis/dermatomyositis.

\section{Primary Sjogren syndrome}

pSS is an autoimmune disease well defined by mononuclear cell infiltrate in the exocrine glands, primarily lacrimal and salivary glands. ${ }^{75}$ The inflammatory infiltrate 
leads to acinar atrophy, which is correlated with ectopic follicles (tertiary lymphoid tissues) composed by lymphocytes, plasma cells and stromal fibrosis. ${ }^{76}$ In the follicles, autoantigens are presented to $\mathrm{T}$ and $\mathrm{B}$ cells and there are germinal centers where autoantibodies can be generated. ${ }^{77}$ Gal-3 serum levels are significantly increased in pSS patients where they are correlated with serum levels of plasma CRP, fibrinogen, IgG and IL-17. ${ }^{78}$ However, the cellular and molecular mechanisms of gal-3 in pSS have been poorly investigated so far (Table 1).

\section{IgA nephropaty}

Glomerulonephritis refers to an immune inflammatory process within renal glomeruli, which is sometimes associated with autoantibodies, eventually leading to end-stage renal disease. ${ }^{55}$ The first step in the development of glomerulonephritis is the activation of TLRs ${ }^{+}$and nod-like receptors $(\mathrm{NLRs})^{+}$cells by PAMPs and DAMPs. ${ }^{79}$ A combined $\mathrm{T}_{\mathrm{H}} 1$ - and $\mathrm{T}_{\mathrm{H}}$ 2-cytokine response induces $\mathrm{CD} 4^{+} \mathrm{T}$-cell differentiation into TGF- $\beta^{+}$IL- $10^{+}$CTLA $4^{+} \mathrm{T}_{\text {reg }}$ cells via TGF- $\beta$ induction, INF- $\gamma^{+} \mathrm{TNF}-\alpha^{+} \mathrm{T}_{\mathrm{H}} 1$ cells via IL-12 induction, IL- $4^{+} \mathrm{IL}_{-} 5^{+} \mathrm{IL}_{13}{ }^{+} \mathrm{T}_{\mathrm{H}} 2$ cells via IL-2, IL-4 and IL-13 induction, or IL- $17^{+}$IL- $21^{+} \mathrm{T}_{\mathrm{H}} 17$ cells via TGF- $\beta$, IL- 6 and IL-17, all of them involved in glomerular injury. ${ }^{80}$

The most prevalent glomerulonephritis in humans is the immunoglobulin A (IgA) nephropathy, which is characterized by huge glomerular deposition of IgA immune complexes leading to renal injury. ${ }^{81}$ IgA nephropathy is hallmarked by high levels of IgA in the serum and poorly galactosylated polymeric IgA1 is widely deposited in the mesangium, following secretion by plasma cells in mucosaassociated lymphoid tissues (MALT) ${ }^{82}$ Since gal-3 was shown to control mesangial cell proliferation and extracellular matrix compounds in a rat model of glomerulonephritis induced by passive transfer of anti-Thy1 antibodies, ${ }^{57}$ it is possible that gal-3 is involved in the pathogenesis of the IgA nephropathy.

Gal-3 protects renal tubules from chronic injury by limiting apoptosis. ${ }^{83}$ Consistently, gal- $3^{-/-}$mice develop pronounced changes in renal function and structure in agerelated renal disease ${ }^{84}$; however, it is not clear whether and how gal-3 regulates renal function. Furthermore, no relationship between gal-3 and renal disease associated with IgA deposition has been demonstrated yet. Recently, Oliveira et al. ${ }^{85}$ demonstrated that IgA expression and secretion are up-regulated in serum and peritoneal fluid in the absence of gal-3, suggesting that IgA-differentiating plasma cells and IgA secretion are at least in part regulated by gal-3. Although gal-3 and IgA nephropathy are not correlated, these observations deserve further studies.

\section{Psoriasis}

Psoriasis is characterized by red and scaly patches in the skin, ridged fingernails, hair loss, painful joints and systemic findings. ${ }^{86}$

Myeloid DCs (mDCs) drives the immunopathogenesis of this immune-mediated inflammatory disease by releasing IL-23 and IL-12, ${ }^{87}$ which are responsible for the activation of $\mathrm{T}_{\mathrm{H}} 17, \mathrm{~T}_{\mathrm{H}} 1$ and $\mathrm{T}_{\mathrm{H}} 22$ cells which produce the "psoriatic cytokines" IL-17, IFN- $\gamma$, TNF and IL-22 affecting keratinocyte functions. ${ }^{88}$ In contrast, $\mathrm{T}_{\text {reg }}$ cells control immune system by preventing autoimmune responses against self-antigens. ${ }^{89}$

The role of gal-3 in the pathogenesis of psoriasis is still poorly understood; however, it has been shown that it is up-regulated in dermal endothelial cells and downmodulated in the epidermis ${ }^{90}$ and Langerhans cells. ${ }^{91}$ The mechanisms involved in these modifications of gal-3 expression have not been studied yet.

\section{Atopic dermatitis}

Atopic dermatitis (AD) is an autoimmune disorder characterized by defective skin barrier, which becomes permissive to penetrating allergens with systemic sensitization ${ }^{92}$ and IgE and IgG anti-nuclear autoantibody production. ${ }^{93}$ It is first driven by a $\mathrm{T}_{\mathrm{H}}$ 2-cytokine phenotype which is then switched to a mix $\mathrm{T}_{\mathrm{H}} 1 / \mathrm{T}_{\mathrm{H}} 2$ phenotype. ${ }^{94}$ In mouse models, gal-3 polarizes immune responses towards a $\mathrm{T}_{\mathrm{H}} 2$ phenotype. ${ }^{43}$ AD-ovalbumin (OVA)-induced mice had high levels of serum gal-3 whereas OVA-sensitized gal-3 $3^{-1-}$ mice developed a $\mathrm{T}_{\mathrm{H}} 1$-polarized immune response associated with a decrease in inflammatory markers, ${ }^{95}$ suggesting that gal-3 may act as an immunomodulatory molecule during early stage of $\mathrm{AD}$.

\section{Multiple sclerosis}

Multiple sclerosis (MS) is the most prevalent autoimmune disease of the central nervous system (CNS) and can be mimicked by experimental autoimmune encephalomyelitis in animal models. The pathogenesis of MS is marked by a potent $\mathrm{T}_{\mathrm{H}} 17$ immune response against demyelinating degenerative cells. $^{96}$ Apoptotic oligodendrocytes are engulfed by microglia in damaged tissues, which are infiltrated by macrophages, T/B lymphocytes, NKT cells and DCs. ${ }^{97,98}$

The involvement of gal-3 in the pathogenesis of MS may be coupled with oligodendrocyte differentiation, since gal-3 contributes to myelin integrity and function. ${ }^{99}$ In gal- $3^{-/-}$ mice, myelinated axons are numerically reduced and the myelin is severely disorganized around axons. ${ }^{99}$ However, during wallerian degeneration, sciatic nerve was rapidly regenerated by Schwann cell activities and the clearance of the myelin debris was significantly efficient in the absence of gal-3. ${ }^{100,101}$ Although the reason is still unclear, gal-3 may play a regulatory role in the development of MS, at least in part by affecting phagocytosis of myelin debris.

\section{Experimental autoimmune encephalomyelitis}

Experimental autoimmune encephalomyelitis (EAE) partially reproduces human MS in experimental animals and is classified as a neuroinflammatory disease orchestrated by self-antigens recognized by autoreactive $T$ cells. $T_{H} 17$ and $\mathrm{T}_{\mathrm{H}} 9$ cells have currently been considered pivotal in the pathogenesis of $\mathrm{EAE}^{102}$ besides the removal of degenerated myelin via phagocytosis mediated by microglia. ${ }^{103}$ In EAE mice, gal-3 is up-regulated by activated microglia during myelin degeneration and phagocytosis in spinal cords and 
optic nerves. ${ }^{104}$ In these activated cells, gal-3 activates PI-3 kinase pathway via rat sarcoma protein (Ras), phagocytosis mediated by complement receptor- 3 and promotes a highaffinity interaction between degenerated myelin (myelin debris) and phagocytosis-receptors during tissue repair. ${ }^{105,106}$

In EAE, gal-3 prevents apoptosis and IL-10 production on the one hand and induces $\mathrm{T}_{\mathrm{H}} 17$ phenotype and IFN- $\gamma$ synthesis on the other hand. In gal-3 $3^{-/-}$mice, EAE was marked by a reduction in monocyte/macrophage infiltration and an increase in apoptotic cells. ${ }^{107}$ Gal-3 regulates T-cell function forming complexes in TCR with Mgat5 (beta1,6 N-acetylglucosaminyltransferase V), an enzyme which exposes $\mathrm{N}$-acetylgalactosamine domain, the binding site of gal-3. ${ }^{108}$ Gal-3 inhibition phenocopies Mgat5 $^{-/-}$TCR clustering and increases the susceptibility to EAE. Thus, gal-3 can be involved in EAE development.

\section{Type I diabetes (T1D)}

The autoimmune type 1 diabetes (T1D) is caused by genetic predisposition and immune dysregulation leading to abnormal autoreactive $\mathrm{T}$ lymphocyte differentiation, pancreatic $\beta$ cell apoptosis and deficient insulin production. ${ }^{109}$ According to genome-wide association studies, pro-apoptotic genes contribute to insulitis and $\beta$-cell destruction. ${ }^{110}$ Gal-3 protects pancreatic $\beta$ cells against IL-1-mediated apoptosis. ${ }^{111}$ On the other hand, inhibition or deletion of galectin-3 renders pancreatic $\beta$-cells more resistant to TNF- $\alpha /$ IFN- $\gamma /$ IL-1 $\beta$ apoptosis. ${ }^{112}$ Probably, extracellular and intracellular gal-3 have a different effect in T1D pathogenesis. Approximately $50 \%$ of pancreatic cells express intracellular gal-3 in healthy tissues. ${ }^{113}$

Gal-3 ${ }^{-/-}$mice are resistant to multiple low-dose streptozotocin-induced diabetes (MLD-STZ) showing modest mononuclear cell recruitment to pancreatic islets, low expression of IFN- $\gamma$ and inducible nitric oxide synthesis (iNOS) and absence of expression of TNF- $\alpha$ and IL-17 in comparison with wild type mice. ${ }^{114}$ The ablation of gal-3 was associated with up-regulation of "anti-apoptotic" genes, suggesting that gal-3 induces apoptosis of islet $\beta$-cells upon pro-inflammatory condition and exposition of autoantigens driving autoimmune responses during early T1D. The mechanism involved in the control of apoptosis on pancreatic $\beta$-cells by gal-3 has not been fully elucidated yet. However, gal-3 seems to play a role in the development of T1D and it could become a promising therapeutic target in T1D patients.

\section{Autoimmune hepatitis (AiH)}

Autoimmune hepatitis ( $\mathrm{AiH})$ is a chronic disease in which apoptotic hepatocytes and portal inflammatory reaction induce a collapse of hepatic lobules. ${ }^{115}$ The pathogenesis of $\mathrm{AiH}$ is initially driven by a $\mathrm{T}_{\mathrm{H}} 1 / \mathrm{T}_{\mathrm{H}} 17$ phenotype marked by infiltrating $\mathrm{CD}^{+}{ }^{\mathrm{T}}$ cell, ${ }^{116,117}$ and is subsequently switched to $\mathrm{T}_{\mathrm{H}} 2$ signature which promotes clonal expansion of autoantibody-secreting plasma cells and inhibits $\mathrm{T}_{\mathrm{H}} 1 / \mathrm{T}_{\mathrm{H}} 17$ functions. ${ }^{118}$ During the dampening of tissue inflammation, $\mathrm{T}_{\text {reg }}$ cells attenuate the immune response ${ }^{119}$ and NKT cells drive a fibrotic response. ${ }^{120}$ Gal-3 is an interesting molecule due to its ability to induce hepatocyte apoptosis ${ }^{121}$ and liver fibrosis, ${ }^{122}$ both orchestrating the activation and differentiation of hepatic stellate cells (HSCs) into myofibroblasts. ${ }^{123}$

Concanavalin-A (Con A)-induced hepatitis is an experimental model that mimics pathological changes observed in AiH patients. ${ }^{124}$ The induction of hepatitis by Con A in gal$3^{-/-}$mice resulted in a weak liver injury, marked by low levels of pro-inflammatory cytokines secreted by hypoactive lymphocytes and DCs and a high number of annexin $\mathrm{V}^{+}$propidium-idodide ${ }^{+}$later apoptotic cells. ${ }^{32}$ Moreover, gal-3 induces myofibroblast activation ${ }^{122}$ and favors phagocytosis by HSCs during liver fibrosis, ${ }^{125}$ indicating that gal3 plays a critical role in the pathogenesis of Con A-induced hepatitis and probably in $\mathrm{AiH}$.

\section{Crohn's disease}

Crohn's disease is an inflammatory bowel disease of autoimmune origin in which genetic predisposition and environmental factors results in abnormal T-cell immune response. ${ }^{126}$ Gal-3 secreted by resident macrophages and colonic epithelial cells activates atypical colonic fibroblasts in lamina propria inducing the production of IL-8 via NF- $\mathrm{KB}$ and driving fistula formation. ${ }^{127}$ During the evolution of the disease, the expression of gal-3 is decreased in the colon interfering with fibroblast migration into fistulae. ${ }^{128}$

Epithelium breakdown was significantly associated with reduced expression of gal-3 and high levels of TNF- $\alpha,{ }^{129}$ suggesting that gal-3 regulates epithelial cell-cell interactions in the colon. In patients affected with Crohn's disease, high serum levels of IgG anti-gal-3 autoantibodies were inversely correlated with clinical symptoms. ${ }^{130}$ By contrast, high levels of gal-3 in the sera and a high number of $\mathrm{CD}_{1}{ }^{+}$cells in the blood of patients with Crohn's disease were found during the active stages of the disease, ${ }^{131}$ Altogether these data suggest that galactin3 can exert a pro-inflammatory effect in Crohn's disease and may have a role in the disease development.

\section{Conclusions and perspectives}

A number of targeted therapies have been tested in patients with autoimmune diseases and some of them were successfully introduced in clinical practice since they were shown to ameliorate disease course, improving quality of life and survival of patients. However, many unmet needs still remain in patients with autoimmune diseases.

Among new molecules capable of regulating immune synapses, histological organization and tissue repair, gal-3 emerged as a multifunctional protein with immunomodulatory effects on cell-fate decisions such as apoptosis, cell activation, differentiation and migration, which are all critical in immune inflammatory responses.

So far, the precise mechanisms by which gal-3 could influence the onset and progression of an autoimmune disorder have not been fully elucidated; however, preliminary data suggest that gal-3 may play a "double-faced" role in regulation of autoimmune responses. Actually, gal-3 may either dampen or foster the development of autoimmune 
disturbances, depending on which mechanisms are prominent in each disease. As an example, gal-3 is able to hinder apoptosis, thereby reducing the autoantigen burden in SLE, yet it can enhance type I IFN responses, thereby worsening autoimmune reactions, which are favored by an IFNenriched environment. In addition, the intracellular or extracellular localization of gal-3 may privilege its antiinflammatory versus its pro-immune attitude, similarly to what was described concerning the intracellular or extracellular isoforms of other molecules involved in modulation of the immune responses. ${ }^{132}$ Interestingly, molecules involved in cellular homeostasis may not rarely become hazardous under aberrant conditions, e.g. an altered cytokine microenvironment or exaggerated antigen exposition, especially when they can affect cellular viability at several levels, as is the case of gal-3.

Involvement of gal-3 in regulation of cell survival and apoptosis is witnessed by gal-3 expression being frequently altered in several malignancies, including lymphomas. ${ }^{22,133}$ Interestingly, several systemic autoimmune disorders display an association with neoplasms, either carcinomas or lymphoproliferative disorders, supporting the concept that intriguing molecules may link autoimmunity and tumorigenesis in the context of autoimmune diseases. Keeping into account all the aspects reviewed here, gal-3 is likely to be involved in the pathogenesis of different autoimmune diseases. Additional studies are required, which can explore the many functions gal-3 is endowed with, in order it can be tested as a therapeutic target in experimental models.

\section{Authors' contribution}

FLO, NB, AG and RL collected experimental data and reviewed all articles cited in the paper; FLO and MG wrote the main text; LP and AD revised the paper. All authors read and approved the final manuscript.

\section{ACKNOWLEDGEMENTS}

This research received no specific grant from any funding agency in the public, commercial, or not-for-profit sectors.

\section{REFERENCES}

1. Dumic J, Dabelic S, Flogel M. Galectin-3: an open-ended story. Biochim Biophys Acta 2006;1760:616-35

2. Chen HY, Liu FT, Yang RY. Roles of galectin-3 in immune responses. Arch Immunol Ther Exp (Warsz) 2005;53:497-504

3. Acosta-Rodríguez EV, Montes CL, Motrán CC, Zuniga EI, Liu FT, Rabinovich GA, Gruppi A. Galectin-3 mediates IL-4-induced survival and differentiation of $\mathrm{b}$ cells: functional cross-talk and implications during trypanosoma cruzi infection. J Immunol 2004;172:493-502

4. Henderson NC, Sethi T. The regulation of inflammation by galectin-3. Immunol Rev 2009;230:160-71

5. Li LC, Li J, Gao J. Functions of galectin-3 and its role in fibrotic diseases. J Pharmacol Exp Ther 2014;351:336-43

6. Funasaka T, Raz A, Nangia-Makker P. Nuclear transport of galectin-3 and its therapeutic implications. Semin Cancer Biol 2014;27:30-8

7. Vasta GR, Ahmed H, Nita-Lazar M, Banerjee A, Pasek M, Shridhar S, Guha P, Fernández-Robledo JA. Galectins as self/non-self recognition receptors in innate and adaptive immunity: an unresolved paradox. Front Immunol 2012;3:199
8. Sato S, Bhaumik P, St-Pierre G, Pelletier I. Role of galectin-3 in the initial control of leishmania infection. Crit Rev Immunol 2014;34:147-75

9. Vasta GR. Roles of galectins in infection. Nat Rev Microbiol 2009;7:424-38

10. Hrynchyshyn N, Jourdain P, Desnos M, Diebold B, Funck F. Galectin-3: a new biomarker for the diagnosis, analysis and prognosis of acute and chronic heart failure. Arch Cardiovasc Dis 2013;106:541-6

11. Vladoiu MC, Labrie M, St-Pierre Y. Intracellular galectins in cancer cells: potential new targets for therapy (review). Int J Oncol 2014;44:1001-14

12. Streetly MJ, Maharaj L, Joel S, Schey SA, Gribben JG, Cotter FE. Gcs-100, a novel galectin-3 antagonist, modulates mcl-1, noxa, and cell cycle to induce myeloma cell death. Blood 2010;115:3939-48

13. Joo HG, Goedegebuure PS, Sadanaga N, Nagoshi M, von Bernstorff W, Eberlein TJ. Expression and function of galectin-3, a beta-galactosidebinding protein in activated T lymphocytes. J Leukoc Biol 2001;69:555-64

14. Hsu DK, Chen HY, Liu FT. Galectin-3 regulates T-cell functions. Immunol Rev 2009;230:114-27

15. Pfoertner S, Jeron A, Probst-Kepper M, Guzman CA, Hansen W, Westendorf AM, Toepfer T, Schrader AJ, Franzke A, Buer J, Geffers R. Signatures of human regulatory T cells: an encounter with old friends and new players. Genome Biol 2006;7:R54

16. Fukumori T, Takenaka Y, Yoshii T, Kim HR, Hogan V, Inohara H, Kagawa S, Raz A. CD29 and CD7 mediate galectin-3-induced type II T-cell apoptosis. Cancer Res 2003;63:8302-11

17. Savino W, Mendes-Da-Cruz DA, Smaniotto S, Silva-Monteiro E, VillaVerde DM. Molecular mechanisms governing thymocyte migration: combined role of chemokines and extracellular matrix. J Leukoc Biol 2004;75:951-61

18. Stowell SR, Qian Y, Karmakar S, Koyama NS, Dias-Baruffi M, Leffler H, McEver RP, Cummings RD. Differential roles of galectin-1 and galectin3 in regulating leukocyte viability and cytokine secretion. J Immunol 2008;180:3091-102

19. Yang RY, Hsu DK, Liu FT. Expression of galectin-3 modulates T-cell growth and apoptosis. Proc Natl Acad Sci USA 1996;93:6737-42

20. Cortegano I, del Pozo V, Cárdaba B, de Andrés B, Gallardo S, del Amo A, Arrieta I, Jurado A, Palomino P, Liu FT, Lahoz C. Galectin-3 down-regulates IL-5 gene expression on different cell types. J Immunol 1998;161:385-9

21. Cerutti A, Chen K, Chorny A. Immunoglobulin responses at the mucosal interface. Annu Rev Immunol 2011;29:273-93

22. Oliveira FL, Brand C, Paula AA, Arcanjo KD, Hsu DK, Liu F-T, Takiya CM, Borojevic R, Chammas R, El-Cheikh MC. Lack of galectin-3 disturbs mesenteric lymph node homeostasis and B cell niches in the course of schistosoma mansoni infection. Plos One 2011;6:e19216

23. Brand C, Oliveira FL, Takiya CM, Palumbo A Jr, Hsu DK, Liu F-T, Chammas R, El-Cheikh MC. The involvement of the spleen during chronic phase of schistosoma mansoni infection in galectin- $3\left(^{-/-}\right)$mice. Histol Histopathol 2012;27:1109-20

24. Oliveira FL, Frazão P, Chammas R, Hsu DK, Liu FT, Borojevic R, Takiya CM, El-Cheikh MC. Kinetics of mobilization and differentiation of lymphohematopoietic cells during experimental murine schistosomiasis in galectin-3 ${ }^{-/-}$mice. J Leukoc Biol 2007;82:300-10

25. Oliveira FL, Chammas R, Ricon L, Fermino ML, Bernardes ES, Hsu DK, Liu FT, Borojevic R, El-Cheikh MC. Galectin-3 regulates peritoneal B1-cell differentiation into plasma cells. Glycobiology 2009;19:1248-58

26. Hoyer KK, Pang M, Gui D, Shintaku IP, Kuwabara I, Liu FT, Said JW, Baum LG, Teitell MA. An anti-apoptotic role for galectin-3 in diffuse large B-cell lymphomas. Am J Pathol 2004;164:893-902

27. Clark AG, Weston ML, Foster MH. Lack of galectin- 1 or galectin-3 alters $B$ cell deletion and anergy in an autoantibody transgene model. Glycobiology 2013;23:893-903

28. Hsu DK, Yang RY, Pan Z, Yu L, Salomon DR, Fung-Leung WP, Liu FT. Targeted disruption of the galectin-3 gene results in attenuated peritoneal inflammatory responses. Am J Pathol 2000;156:1073-83

29. Vray B, Camby I, Vercruysse V, Mijatovic T, Bovin NV, RicciardiCastagnoli P, Kaltner H, Salmon I, Gabius HJ, Kiss R. Up-regulation of galectin-3 and its ligands by trypanosoma cruzi infection with modulation of adhesion and migration of murine dendritic cells. Glycobiology 2004;14:647-57 
30. Bernardes ES, Silva NM, Ruas LP, Mineo JR, Loyola AM, Hsu DK, Liu FT, Chammas R, Roque-Barreira MC. Toxoplasma gondii infection reveals a novel regulatory role for galectin-3 in the interface of innate and adaptive immunity. Am J Pathol 2006;168:1910-20

31. Breuilh L, Vanhoutte F, Fontaine J, van Stijn CM, Tillie-Leblond I, Capron M, Faveeuw C, Jouault T, van Die I, Gosset P, Trottein F. Galectin-3 modulates immune and inflammatory responses during helminthic infection: impact of galectin-3 deficiency on the functions of dendritic cells. Infect Immun 2007;75:5148-57

32. Volarevic V, Milovanovic M, Ljujic B, Pejnovic N, Arsenijevic N, Nilsson U, Leffler H, Lukic ML. Galectin-3 deficiency prevents concanavalin A-induced hepatitis in mice. Hepatology 2012;55:1954-64

33. Zen M, Bassi N, Nalotto L, Canova M, Bettio S, Gatto M, Ghirardello A, Iaccarino L, Punzi L, Doria A. Disease activity patterns in a monocentric cohort of SLE patients: a seven-year follow-up study. Clin Exp Rheumatol 2012;30:856-63

34. Gatto M, Zen M, Ghirardello A, Bettio S, Bassi N, Iaccarino L, Punzi L, Doria A. Emerging and critical issues in the pathogenesis of lupus. Autoimmun Rev 2013;12:523-36

35. Craft JE. Dissecting the immune cell mayhem that drives lupus pathogenesis. Sci Transl Med 2011;3:73ps79

36. Gatto M, Kiss E, Naparstek Y, Doria A. In-/off-label use of biologic therapy in systemic lupus erythematosus. BMC Med 2014;12:30

37. Vinuesa CG, Sanz I, Cook MC. Dysregulation of germinal centres in autoimmune disease. Nat Rev Immunol 2009;9:845-57

38. Kang EH, Moon KC, Lee EY, Lee YJ, Lee EB, Ahn C, Song YW. Renal expression of galectin-3 in systemic lupus erythematosus patients with nephritis. Lupus 2009;18:22-8

39. Luzina IG, Atamas SP, Storrer CE, daSilva LC, Kelsoe G, Papadimitriou JC, Handwerger BS. Spontaneous formation of germinal centers in autoimmune mice. J Leukoc Biol 2001;70:578-84

40. Azevedo PC, Murphy G, Isenberg DA. Pathology of systemic lupus erythematosus: the challenges ahead. Methods Mol Biol 2014;1134:1-16

41. Villa-Verde DM, Silva-Monteiro E, Jasiulionis MG, Farias-DeOliveira DA, Brentani RR, Savino W, Chammas R. Galectin-3 modulates carbohydrate-dependent thymocyte interactions with the thymic microenvironment. Eur J Immunol 2002;32:1434-44

42. Wu SY, Yu JS, Liu FT, Miaw SC, Wu-Hsieh BA. Galectin-3 negatively regulates dendritic cell production of IL-23/IL-17-axis cytokines in infection by histoplasma capsulatum. J Immunol 2013;190:3427-37

43. Fermin Lee A, Chen HY, Wan L, Wu SY, Yu JS, Huang AC, Miaw SC, Hsu DK, Wu-Hsieh BA, Liu FT. Galectin-3 modulates Th17 responses by regulating dendritic cell cytokines. Am J Pathol 2013;183:1209-22

44. Mak A, Kow NY. The pathology of T cells in systemic lupus erythematosus. J Immunol Res 2014;2014:419029

45. Santiago-Raber ML, Baccala R, Haraldsson KM, Choubey D, Stewart TA, Kono DH, Theofilopoulos AN. Type-I interferon receptor deficiency reduces lupus-like disease in NZB mice. J Exp Med 2003;197:777-88

46. Means TK, Latz E, Hayashi F, Murali MR, Golenbock DT, Luster AD. Human lupus autoantibody-DNA complexes activate DCs through cooperation of CT32 and TLR9. J Clin Invest 2005;115:407-17

47. Lande R, Ganguly D, Facchinetti V, Frasca L, Conrad C, Gregorio J, Meller S, Chamilos G, Sebasigari R, Riccieri V, Bassett R, Amuro H, Fukuhara S, Ito T, Liu YJ, Gilliet M. Neutrophils activate plasmacytoid dendritic cells by releasing self-DNA-peptide complexes in systemic lupus erythematosus. Sci Transl Med 2011;3:73ra19

48. Bennett L, Palucka AK, Arce E, Cantrell V, Borvak J, Banchereau J, Pascual V. Interferon and granulopoiesis signatures in systemic lupus erythematosus blood. J Exp Med 2003;197:711-23

49. Kim SJ, Zou YR, Goldstein J, Reizis B, Diamond B. Tolerogenic function of Blimp-1 in dendritic cells. J Exp Med 2011;208:2193-9

50. Teichmann LL, Ols ML, Kashgarian M, Reizis B, Kaplan DH, Shlomchik MJ. Dendritic cells in lupus are not required for activation of $\mathrm{T}$ and $\mathrm{B}$ cells but promote their expansion, resulting in tissue damage. Immunity 2010;33:967-78

51. Sarter K, Janko C, Andre S, Munoz LE, Schorn C, Winkler S, Rech J, Kaltner H, Lorenz HM, Schiller M, Andreoli L, Manfredi AA, Isenberg DA, Schett G, Herrmann M, Gabius HJ. Autoantibodies against galectins are associated with antiphospholipid syndrome in patients with systemic lupus erythematosus. Glycobiology 2013;23:12-22

52. Lim Y, Lee DY, Lee S, Park SY, Kim J, Cho B, Lee H, Kim HY, Lee E, Song YW, Jeoung DI. Identification of autoantibodies associated with systemic lupus erythematosus. Biochem Biophys Res Commun 2002;295:119-24

53. Shi ZR, Tan GZ, Meng Z, Yu M, Li KW, Yin J, Wei KH, Luo YJ, Jia SQ, Zhang SJ, Wu J, Mi XB, Wang L. Association of anti-acidic ribosomal protein $\mathrm{P} 0$ and anti-galectin 3 antibodies with the development of skin lesions in systemic lupus erythematosus. Arthritis Rheumatol 2015;67:193-203

54. Doria A, Gatto M. Nephritogenic-antinephritogenic antibody network in lupus glomerulonephritis. Lupus 2012;21:1492-6

55. Ooi JD, Gan PY, Odobasic D, Holdsworth SR, Kitching AR. T cell mediated autoimmune glomerular disease in mice. Curr Protoc Immunol 2014;107:15.27.11-15.27.19

56. Fenton K. The effect of cell death in the initiation of lupus nephritis. Clin Exp Immunol 2015;179:11-6

57. Sasaki S, Bao Q, Hughes RC. Galectin-3 modulates rat mesangial cell proliferation and matrix synthesis during experimental glomerulonephritis induced by anti-Thy1.1. antibodies. J Pathol 1999;187:481-9

58. Nielsen CT, Ostergaard O, Rekvig OP, Sturfelt G, Jacobsen S, Heegaard NH. Galectin-3 binding protein links circulating microparticles with electron dense glomerular deposits in lupus nephritis. Lupus2015;Epub ahead of print 2 April. DOI: 0961203315580146)

59. Korczowska I. Rheumatoid arthritis susceptibility genes: an overview. World J Orthop 2014;5:544-9

60. Niu Q, Cai B, Huang ZC, Shi YY, Wang LL. Disturbed Th17/Treg balance in patients with rheumatoid arthritis. Rheumatol Int 2012;32:2731-6

61. Cooles FA, Isaacs JD, Anderson AE. Treg cells in rheumatoid arthritis: an update. Curr Rheumatol Rep 2013;15:352

62. Forsman H, Islander U, Andreasson E, Andersson A, Onnheim K, Karlstrom A, Sävman K, Magnusson M, Brown KL, Karlsson A. Galectin 3 aggravates joint inflammation and destruction in antigeninduced arthritis. Arthritis Rheum 2011;63:445-54

63. Wang CR, Shiau AL, Chen SY, Cheng ZS, Li YT, Lee CH, Yo YT, Lo CW, Lin YS, Juan HY, Chen YL, Wu CL. Intra-articular lentivirus-mediated delivery of galectin-3 shRNA and galectin-1 gene ameliorates collageninduced arthritis. Gene Ther 2010;17:1225-33

64. Filer A, Bik M, Parsonage GN, Fitton J, Trebilcock E, Howlett K, Cook M, Raza K, Simmons DL, Thomas AM, Salmon M, ScheelToellner D, Lord JM, Rabinovich GA, Buckley CD. Galectin 3 induces a distinctive pattern of cytokine and chemokine production in rheumatoid synovial fibroblasts via selective signaling pathways. Arthritis Rheum 2009;60:1604-14

65. Hu CY, Chang SK, Wu CS, Tsai WI, Hsu PN. Galectin-3 gene (LGALS3) + 292C allele is a genetic predisposition factor for rheumatoid arthritis in Taiwan. Clin Rheumatol 2011;30:1227-33

66. Cozzi F, Marson P, Cardarelli S, Favaro M, Tison T, Tonello M, Pigatto E, De Silvestro G, Punzi L, Doria A. Prognosis of scleroderma renal crisis: a long-term observational study. Nephrol Dial Transplant 2012;27:4398-403

67. Taniguchi T, Asano Y, Akamata K, Noda S, Masui Y, Yamada D, Takahashi T, Ichimura Y, Toyama T, Tamaki Z, Tada Y, Sugaya M, Kadono T, Sato S. Serum levels of galectin-3: possible association with fibrosis, aberrant angiogenesis, and immune activation in patients with systemic sclerosis. J Rheumatol 2012;39:539-44

68. Koca SS, Akbas F, Ozgen M, Yolbas S, Ilhan N, Gundogdu B, Isik A. Serum galectin-3 level in systemic sclerosis. Clin Rheumatol 2014;33:215-20

69. Iaccarino L, Ghirardello A, Bettio S, Zen M, Gatto M, Punzi L, Doria A. The clinical features, diagnosis and classification of dermatomyositis. J Autoimmun 2014;48-49:122-7

70. Ghirardello A, Zampieri S, Tarricone E, Iaccarino L, Bendo R, Briani C, Rondinone R, Sarzi-Puttini P, Todesco S, Doria A. Clinical implications of autoantibody screening in patients with autoimmune myositis. Autoimmunity 2006;39:217-21

71. Ghirardello A, Bassi N, Palma L, Borella E, Domeneghetti M, Punzi L, Doria A. Autoantibodies in polymyositis and dermatomyositis. Curr Rheumatol Rep 2013;15:335 
72. Luo YB, Mastaglia FL. Dermatomyositis, polymyositis and immunemediated necrotising myopathies. Biochim Biophys Acta 2015;1852:622-32

73. Nalotto L, Iaccarino L, Zen M, Gatto M, Borella E, Domenighetti M, Punzi L, Doria A. Rituximab in refractory idiopathic inflammatory myopathies and antisynthetase syndrome: personal experience and review of the literature. Immunol Res 2013;56:362-70

74. Lundberg IE, Vencovsky J, Alexanderson H. Therapy of myositis: biological and physical. Curr Opin Rheumatol 2014;26:704-11

75. Tincani A, Andreoli L, Cavazzana I, Doria A, Favero M, Fenini MG, Franceschini F, Lojacono A, Nascimbeni G, Santoro A, Semeraro F, Toniati P, Shoenfeld Y. Novel aspects of Sjögren's syndrome in 2012. BMC Med 2013;11:93

76. Llamas-Gutierrez FJ, Reyes E, Martinez B, Hernandez-Molina G. Histopathological environment besides the focus score in Sjögren's syndrome. Int J Rheum Dis 2014;17:898-903

77. Karnell JL, Mahmoud TI, Herbst R, Ettinger R. Discerning the kinetics of autoimmune manifestations in a model of sjogren's syndrome. Mol Immunol 2014;62:277-82

78. Zhang R, Sun T, Song L, Zuo D, Xiao W. Increased levels of serum galectin-3 in patients with primary Sjögren's syndrome: associated with interstitial lung disease. Cytokine 2014;69:289-93

79. Couser WG, Johnson RJ. The etiology of glomerulonephritis: roles of infection and autoimmunity. Kidney Int 2014;86:905-14

80. Couser WG. Basic and translational concepts of immune-mediated glomerular diseases. J Am Soc Nephrol 2012;23:381-99

81. Zhang C, Zeng X, Li Z, Wang Z, Li S. Immunoglobulin A nephropathy: current progress and future directions. Transl Res2015;Epub ahead of print 4 March. DOI: 10.1016/j.trs1.2015.02.007)

82. Meng H, Ohtake H, Ishida A, Ohta N, Kakehata S, Yamakawa M. IgA production and tonsillar focal infection in iga nephropathy. J Clin Exp Hematop 2012;52:161-70

83. Okamura DM, Pasichnyk K, Lopez-Guisa JM, Collins S, Hsu DK, Liu FT, Eddy AA. Galectin-3 preserves renal tubules and modulates extracellular matrix remodeling in progressive fibrosis. Am J Physiol Renal Physiol 2011;300:F245-53

84. Iacobini C, Oddi G, Menini S, Amadio L, Ricci C, Di Pippo C, Sorcini M, Pricci F, Pugliese F, Pugliese G. Development of age-dependent glomerular lesions in galectin-3/age-receptor-3 knockout mice. Am J Physiol Renal Physiol 2005;289:F611-21

85. Oliveira FL, Bernardes ES, Brand C, Santos S, Cabanel MP, Arcanjo KD, Brito JM, Borojevic R, Chammas R, El-Cheikh MC. The lack of galectin-3 up-regulates IgA expression by peritoneal B1 lymphocytes during B cell differentiation. Cell Tissue Res2015;Epub ahead of print 24 May, DOI 10.1007/s00441-015-2203-y)

86. Ryan C, Korman NJ, Gelfand JM, Lim HW, Elmets CA, Feldman SR, Gottlieb AB, Koo JY, Lebwohl M, Leonardi CL, Van Voorhees AS, Bhushan R, Menter A. Research gaps in psoriasis: opportunities for future studies. J Am Acad Dermatol 2014;70:146-67

87. Mitra A, Fallen RS, Lima HC. Cytokine-based therapy in psoriasis. Clin Rev Allergy Immunol 2013;44:173-82

88. Nograles KE, Zaba LC, Guttman-Yassky E, Fuentes-Duculan J, Suarez-Farinas M, Cardinale I, Khatcherian A, Gonzalez J, Pierson KC, White TR, Pensabene C, Coats I, Novitskaya I, Lowes MA, Krueger JG. Th17 cytokines interleukin (IL)-17 and IL-22 modulate distinct inflammatory and keratinocyte-response pathways. Br J Dermatol 2008;159:1092-102

89. Mattozzi C, Salvi M, D’Epiro S, Giancristoforo S, Macaluso L, Luci C, Lal K, Calvieri S, Richetta AG. Importance of regulatory T cells in the pathogenesis of psoriasis: review of the literature. Dermatology 2013;227:134-45

90. Lacina L, Plzakova Z, Smetana K Jr, Stork J, Kaltner H, Andre S. Glycophenotype of psoriatic skin. Folia Biol (Praha) 2006;52:10-15

91. de la Fuente H, Perez-Gala S, Bonay P, Cruz-Adalia A, Cibrian D, Sanchez-Cuellar S, Dauden E, Fresno M, García-Diez A, SanchezMadrid F. Psoriasis in humans is associated with down-regulation of galectins in dendritic cells. J Pathol 2012;228:193-203

92. Just J, Deslandes-Boutmy E, Amat F, Desseaux K, Nemni A, Bourrat E, Sahraoui F, Pansé I, Bagot M, Fouéré S. Natural history of allergic sensitization in infants with early-onset atopic dermatitis: results from orca study. Pediatr Allergy Immunol 2014;25:668-73

93. Muro Y. Autoantibodies in atopic dermatitis. J Dermatol Sci 2001;25:171-8

94. Rahman S, Collins M, Williams CM, Ma HL. The pathology and immunology of atopic dermatitis. Inflamm Allergy Drug Targets 2011;10:486-96

95. Saegusa J, Hsu DK, Chen HY, Yu L, Fermin A, Fung MA, Liu FT. Galectin-3 is critical for the development of the allergic inflammatory response in a mouse model of atopic dermatitis. Am J Pathol 2009;174:922-31

96. Compston A, Coles A. Multiple sclerosis. Lancet 2008;372:1502-17

97. Prineas JW, Parratt JD. Oligodendrocytes and the early multiple sclerosis lesion. Ann Neurol 2012;72:18-31

98. Hoglund RA, Maghazachi AA. Multiple sclerosis and the role of immune cells. World J Exp Med 2014;4:27-37

99. Pasquini LA, Millet V, Hoyos HC, Giannoni JP, Croci DO, Marder M, Liu FT, Rabinovich GA, Pasquini JM. Galectin-3 drives oligodendrocyte differentiation to control myelin integrity and function. Cell Death Differ 2011;18:1746-56

100. Narciso MS, Mietto Bde S, Marques SA, Soares CP, Mermelstein Cdos S, El-Cheikh MC, Martinez AM. Sciatic nerve regeneration is accelerated in galectin-3 knockout mice. Exp Neurol 2009;217:7-15

101. Mietto BS, Jurgensen S, Alves L, Pecli C, Narciso MS, AssuncaoMiranda I, Villa-Verde DM, de Souza Lima FR, de Menezes JR, Benjamim CF, Bozza MT, Martinez AM. Lack of galectin-3 speeds wallerian degeneration by altering TLR and pro-inflammatory cytokine expressions in injured sciatic nerve. Eur J Neurosci 2013;37:1682-90

102. Petermann F, Korn T. Cytokines and effector t cell subsets causing autoimmune cns disease. FEBS Lett 2011;585:3747-57

103. Smith ME. Phagocytic properties of microglia in vitro: implications for a role in multiple sclerosis and EAE. Microsc Res Tech 2001;54:81-94

104. Reichert F, Rotshenker S. Galectin-3/MAC-2 in experimental allergic encephalomyelitis. Exp Neurol 1999;160:508-14

105. Rotshenker S, Reichert F, Gitik M, Haklai R, Elad-Sfadia G, Kloog Y. Galectin-3/MAC-2, RAS and PI3K activate complement receptor-3 and scavenger receptor-AI/II mediated myelin phagocytosis in microglia. Glia 2008;56:1607-13

106. Brown GC, Neher JJ. Microglial phagocytosis of live neurons. Nat Rev Neurosci 2014;15:209-16

107. Jiang HR, Al Rasebi Z, Mensah-Brown E, Shahin A, Xu D, Goodyear CS, Fukada SY, Liu FT, Liew FY, Lukic ML. Galectin-3 deficiency reduces the severity of experimental autoimmune encephalomyelitis. J Immunol 2009;182:1167-73

108. Demetriou M, Granovsky M, Quaggin S, Dennis JW. Negative regulation of T-cell activation and autoimmunity by Mgat5 N-glycosylation. Nature 2001;409:733-9

109. Roep BO, Tree TI. Immune modulation in humans: implications for type 1 diabetes mellitus. Nat Rev Endocrinol 2014;10:229-42

110. Santin I, Eizirik DL. Candidate genes for type 1 diabetes modulate pancreatic islet inflammation and beta-cell apoptosis. Diabetes Obes Metab 2013;15(Suppl 3): 71-81

111. Karlsen AE, Storling ZM, Sparre T, Larsen MR, Mahmood A, Størling J, Roepstorff P, Wrzesinski K, Larsen PM, Fey S, Nielsen K, Heding P, Ricordi C, Johannesen J, Kristiansen OP, Christensen UB, Kockum I, Luthman H, Nerup J, Pociot F. Immune-mediated beta-cell destruction in vitro and in vivo-a pivotal role for galectin-3. Biochem Biophys Res Commun 2006;344:406-15

112. Saksida T, Nikolic I, Vujicic M, Nilsson UJ, Leffler H, Lukic ML, Stojanovic I, Stosic-Grujicic S. Galectin-3 deficiency protects pancreatic islet cells from cytokine-triggered apoptosis in vitro. J Cell Physiol 2013;228:1568-76

113. Schaffert C, Pour PM, Chaney WG. Localization of galectin-3 in normal and diseased pancreatic tissue. Int J Pancreatol 1998;23:1-9

114. Mensah-Brown EP, Al Rabesi Z, Shahin A, Al Shamsi M, Arsenijevic N, Hsu DK, Liu FT, Lukic ML. Targeted disruption of the galectin-3 gene results in decreased susceptibility to multiple low dose streptozotocininduced diabetes in mice. Clin Immunol 2009;130:83-8 
115. Gleeson D, Heneghan MA. British society of gastroenterology (BSG) guidelines for management of autoimmune hepatitis. Gut 2011;60:1611-29

116. Yu H, Huang J, Liu Y, Ai G, Yan W, Wang X, Ning Q. IL-17 contributes to autoimmune hepatitis. J Huazhong Univ Sci Technolog Med Sci 2010;30:443-6

117. Lohr H, Manns M, Kyriatsoulis A, Lohse AW, Trautwein C, Meyer zum Buschenfelde KH, Fleischer B. Clonal analysis of liver-infiltrating T cells in patients with LKM-1 antibody-positive autoimmune chronic active hepatitis. Clin Exp Immunol 1991;84:297-302

118. Harrington LE, Hatton RD, Mangan PR, Turner H, Murphy TL, Murphy KM, Weaver CT. Interleukin 17-producing CD4+ effector T cells develop via a lineage distinct from the T helper type 1 and 2 lineages. Nat Immunol 2005;6:1123-32

119. Sakaguchi S. Naturally arising Foxp3-expressing CD25+CD4 + regulatory Tcells in immunological tolerance to self and non-self. Nat Immunol 2005;6:345-52

120. de Lalla C, Galli G, Aldrighetti L, Romeo R, Mariani M, Monno A, Nuti S, Colombo M, Callea F, Porcelli SA, Panina-Bordignon P, Abrignani S, Casorati G, Dellabona P. Production of profibrotic cytokines by invariant NKT cells characterizes cirrhosis progression in chronic viral hepatitis. J Immunol 2004;173:1417-25

121. Czaja AJ. Targeting apoptosis in autoimmune hepatitis. Dig Dis Sci 2014;59:2890-4

122. Henderson NC, Mackinnon AC, Farnworth SL, Poirier F, Russo FP, Iredale JP, Haslett C, Simpson KJ, Sethi T. Galectin-3 regulates myofibroblast activation and hepatic fibrosis. Proc Natl Acad Sci USA 2006;103:5060-5

123. Czaja AJ. Review article: chemokines as orchestrators of autoimmune hepatitis and potential therapeutic targets. Aliment Pharmacol Ther 2014;40:261-79

124. Wang HX, Liu M, Weng SY, Li JJ, Xie C, He HL, Guan W, Yuan YS, Gao J. Immune mechanisms of concanavalin a model of autoimmune hepatitis. World J Gastroenterol 2012;18:119-25

125. Jiang JX, Chen X, Hsu DK, Baghy K, Serizawa N, Scott F, Takada Y, Takada Y, Fukada H, Chen J, Devaraj S, Adamson R, Liu FT, Török NJ.
Galectin-3 modulates phagocytosis-induced stellate cell activation and liver fibrosis in vivo. Am J Physiol Gastrointest Liver Physiol 2012;302:G439-46

126. Mudter J, Neurath MF. Insight into Crohn's disease pathomorphology. Abdom Imaging 2012;37:921-6

127. Lippert E, Falk W, Bataille F, Kaehne T, Naumann M, Goeke M, Herfarth H, Schoelmerich J, Rogler G. Soluble galectin-3 is a strong, colonic epithelial-cell-derived, lamina propria fibroblast-stimulating factor. Gut 2007;56:43-51

128. Lippert E, Gunckel M, Brenmoehl J, Bataille F, Falk W, Scholmerich J, Obermeier F, Rogler G. Regulation of galectin-3 function in mucosal fibroblasts: potential role in mucosal inflammation. Clin Exp Immunol 2008;152:285-97

129. Jensen-Jarolim E, Gscheidlinger R, Oberhuber G, Neuchrist C, Lucas T, Bises G, Radauer C, Willheim M, Scheiner O, Liu FT, BoltzNitulescu G. The constitutive expression of galectin-3 is downregulated in the intestinal epithelia of Crohn's disease patients, and tumour necrosis factor alpha decreases the level of galectin-3-specific mRNA in HCT-8 cells. Eur J Gastroenterol Hepatol 2002;14:145-52

130. Jensen-Jarolim E, Neumann C, Oberhuber G, Gscheidlinger R, Neuchrist C, Reinisch W, Zuberi RI, Penner E, Liu FT, BoltzNitulescu G. Anti-galectin-3 IgG autoantibodies in patients with Crohn's disease characterized by means of phage display peptide libraries. J Clin Immunol 2001;21:348-56

131. Frol'ova L, Smetana K Jr, Borovska D, Kitanovicova A, Klimesova K, Janatkova I, Malícková K, Lukás M, Drastich P, Benes Z, Tucková L, Manning JC, André S, Gabius HJ, Tlaskalová-Hogenová H. Detection of galectin-3 in patients with inflammatory bowel diseases: new serum marker of active forms of IBD? Inflamm Res 2009;58:503-12

132. Gatto M, Iaccarino L, Ghirardello A, Bassi N, Pontisso P, Punzi L, Shoenfeld Y, Doria A. Serpins, immunity and autoimmunity: old molecules, new functions. Clin Rev Allergy Immunol 2013;45:267-80

133. Ikemori RY, Machado CM, Furuzawa KM, Nonogaki S, Osinaga E, Umezawa K, de Carvalho MA, Verinaud L, Chammas R. Galectin-3 up-regulation in hypoxic and nutrient deprived microenvironments promotes cell survival. PLoS One 2014;9:e111592 